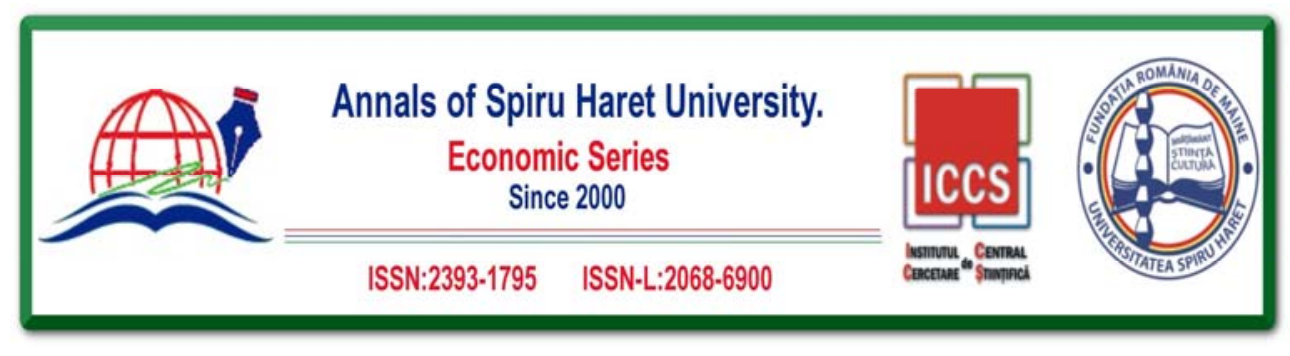

Issue 1/2019

\title{
TERTIARY EDUCATION - ONE OF THE MAJOR EUROPE 2020 OBJECTIVES
}

\author{
Daliana Ecaterina TASCOVICI ${ }^{1}$, Carolina PLATON ${ }^{2}$ \\ ${ }^{1}$ Spiru Haret University, Faculty of Economic Sciences, no. 223, \\ Traian str., Campulung, 115100, Romania, Tel.: +40742439416, \\ Email: tascovici.daliana@spiruharet.ro \\ ${ }^{2}$ State University, Chișinău, Moldova Republic, \\ Email: carolina.celenti@gmail.com
}

How to cite: TAȘCOVICI, D. E., PLATON, C. (2019). “Tertiary Education - One ot the Major Europe 2020 Objectives." Annals of Spiru Haret University. Economic Series, 19(1), 23-30, doi: https://doi.org/10.26458/1912

\begin{abstract}
The present paper speaks about the changes the Romanian system of learning suffers. Under these circumstances of social, political, economic and cultural changes and challenges, the pre-university and university systems of learning have to cover several forms and situations, namely those high school graduates without the baccalaureate diploma. The case study under analysis revealed some unexpected pieces of information referring to the young undergraduates' vulnerabilities and degree of information and implication in their own future.
\end{abstract}

Keywords: Romanian system of learning; tertiary education; school abandon

JEL Clasification: I20; I25

\section{Introduction}

For the 2015-2020 period, Romania established the national strategy referring to the tertiary education development. In order to reach its goal, as this strategy become operational, analyses, elaborations and evaluations are proposed for the relevant politics and initiatives.

This strategy is connected and subordinated to the national strategy for competitiveness 2015-2020. It wants to identify the needs as concern the competences 


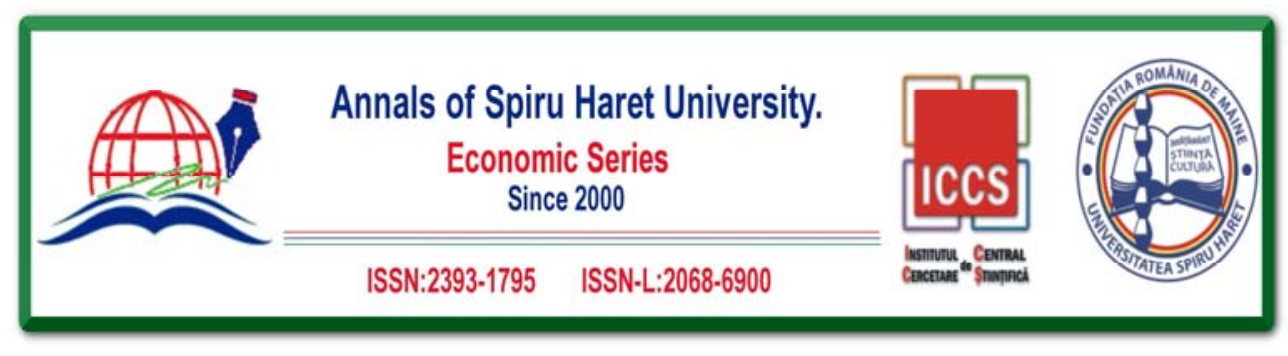

Issue 1/2019

for a smooth and gradually passing towards a knowledge-based economy, a high level of demand and, by default, high qualified jobs. Of course, the tertiary education is only one component of the system of learning and it cannot administrate by itself the present reality, dominated by competitiveness and challenges. Thus, the specialists agree that the main element of the strategy is the improving of the human resources. These, in their turn, can face competitiveness long-term.

As we mentioned above, the strategy referring to tertiary education proposes actions and objectives complementary to the strategy of research and development for the system of education. The tertiary education is promoted as a vector of the economic growth based on knowledge and high qualification. Romania has to surpass the present period characterized by cheap labour force; this tactics attracted jobs, indeed, for the internal market. The global situation at present imposes the improvement of the efficiency in the production process and products quality. The internal force labour, comprising employees, graduates of the tertiary education, possessors of necessary abilities and aptitudes, contributes to achieving these aims.

\section{Literature Review}

The specialists who wrote about this subject stressed the importance of the tertiary educational institutions as mandated by legislation to produce high level skilled and knowledgeable human resources that are required for the economic growth of the country [Naris, \& Ukpere, 2012]; or they analyzed the labour emigration, the labour market in Romania and noticed they are not capable of absorbing the restructured unemployment surpluses on the background of the jobs offer diminution and of the changes in the structure of the labour demand [Gheorghiță, 2015]; others uttered that by building a strong and high-quality education system, the economies of a country will provide further growth and development in the future. Education and training are seen as key investments when it comes to the formation of human capital. Over time, they will secure the acquisition of a better job, which will result in the realization of higher income of these individuals. They are considered crucial when it comes to the impact and degree of national economies. A higher level of education of the workforce will accelerate economic prosperity [Ilić, et al., 2017]; other mention the vision of the updated Employment Strategy 2013-2020 as being defined as: ensure conditions and opportunities for improving the quality of the workforce and increasing employment in the economy of smart, sustainable and inclusive growth to raise living standards 24 


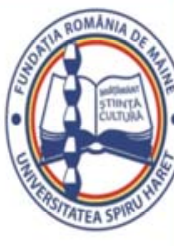

Issue 1/2019

and promote social inclusion [Terziev, \& Arabska, 2015]. Australian authors speak about challenges and opportunities in the introduction of a tertiary education program, but only as a case study [Harvey, \& Walsh, 2018]. Other topics of interest in this field try to answer the question: how can we contribute to the subversion of gender normalcy in Physical Education and Sport Tertiary Education [Devis-Devis, et al., 2018]. More sensitive aspects concern social justice in a tertiary education context [Gair, \& Baglow, 2018]. A promotional brochure for prospective students is the feature that raises interest for Australian specialists in tertiary education [Riccardo, 2018]; digital media framework in tertiary science education preoccupies other specialists in the field [Reyna, \& Meier, 2018], as well as teachers' perceptions [Isiyaku, et al., 2018].

As we can see above, the field is wide and the specialists' preoccupations and interest are very diverse and cover a lot of aspects. In our country, major contributions to this domain are expected to be revealed.

\section{Theoretical Background - Objectives of Europe 2020}

The Govern Strategy for reaching the objectives of Europe 2020 consists of measures referring to the educational system. We mention some of them:

- $75 \%$ of the population between the age of 20 and 64 has to be occupied;

- The percentage of the pupils abandoning school early has to be under $10 \%$;

- At least $40 \%$ of the population between the age of 30 and 34 has to graduate the tertiary education;

- At least $15 \%$ of the population between the age of 25 and 64 has to participate at long life learning;

- The European objective establishes $26.7 \%$ of the population between the age of 30 and 34 graduate the tertiary education up to 2020 [https://www.edu.ro].

Among the roles and benefits of the tertiary education are:

- the stimulus of the economic growth;

- contributes to the productivity growth;

- promotes the social cohesion.

In order to improve the participation to the tertiary education, one proposes the following:

- the establishing of a clear route from the secondary professional education and other type of education to the tertiary education; 


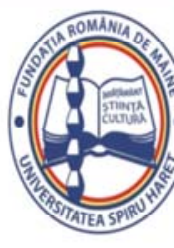

Issue 1/2019

- the exemption from the rate of tax, depending on the merits and a scholarship program based on necessities;

- the implementation of a credit program for education;

- the encouraging of the students attraction from under-represented groups and non-traditional groups, including the adults;

- the increasing of the information transparency program and guidance referring to opportunities and educational results in order for the students to be informed when choosing the educational route and also the reduction of the school abandon.

\section{Research}

Our present study is a pilot one and aims at presenting the perception of the learning subjects - teachers and pupils - on this new form of education: the tertiary education. The concept is fairly new, as mentioned, but there have past almost six years since its implementation. Despite the national strategy as concerns the tertiary education, people are not informed about it, do not know much about its specific features, components and benefits. Our study comprises a small number of respondents, it has not the pretention of a representative analysis, but it reflects, nevertheless, the present situation, as we observed it in formal and non-formal meetings and discussions with teachers and pupils in the pre-university system of learning. The study is part of an ample research we develop this year: the following steps propose the analysis of the tertiary education as a national strategy for competitiveness, as mentioned by the Romanian authorities.

Taking into account the above-mentioned aspects and drawbacks, we have identified from the conjunction of the system of education with the realities of the economics and social realities we were evolve in, and we have elaborated a questionnaire - The questionnaire recording the perception of the non-university tertiary education; this was applied to both teachers and high school undergraduates in their final form; the respondents attend schools, high school or colleges, that is pre-university institutions of education in Campulung town. The questionnaires comprise nine questions with small differences between the questions for teachers and the questions for pupils.

The questionnaires addressed to the teachers revealed the following aspects: from 32 questionnaires, we validated 31. All the respondents have between 15 and 


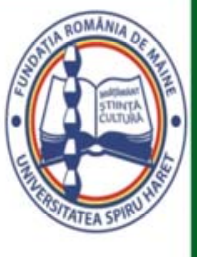

Issue 1/2019

25 years of teaching experience, and are, in a great majority females, as those predominate in schools: $60 \%$.

The results of the questionnaire addressed to the pupils reveal the following data: from 43 answers, we validated 41 , this is $95 \%$. The pupils attend mathematicsinformatics or philology profile; they are between 17 and 18 years old; their marks are high, above 8.50 , and there are $54 \%$ female and $46 \%$ male.

At the question: How well is the concept of tertiary education to you? - all of the teachers, that is $100 \%$, answered: insufficiently, on a scale of five categories of response: very well, well, sufficient, insufficient, not at all. This response reveals the first big problem this concept is face with: it was not presented enough; not even the teachers know sufficiently about it. This response is in accordance to that offered by the pupils: $93 \%$ of them do not know about this form of education. This concept has appeared in the educational policies of Romania since 2015. The pupils do not know much about it, thus they could not choose this education route. The partial conclusion we can draw is that the tertiary education was not promoted enough.

The next question - Do you know the specific features of this form of education? - is connected to the previous one and received only negative answers: all of the pupils said they do not know the specific of the tertiary education. The pupils' answer is in accordance with that of the teachers: the entire latter category said they consider this form of education not to be well known.

The question no. seven - Are you interested in attending a tertiary program in case of passing the baccalaureate exam? - offers the respondents a minimum documentation about the tertiary education and its features; thus, the responses met the following values: $83 \%$ are not interested and $17 \%$ are. We have to mention that the respondents attend good theoretical high-schools, with baccalaureate promotion rate bigger than $90 \%$ and annual study grades over 8.50 ; under these circumstances, it is clear that they have already decided their future professional career.

The eighth question - Are you interested in attending a tertiary program in case of not passing the baccalaureate exam? - received the following options: $22 \%$ would not attend this type of courses and $78 \%$ would be interested in.

The above presented results are better seen in the figure below, fig. 1: 


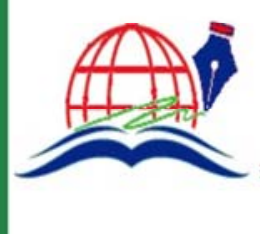

Annals of Spiru Haret University.

Economic Series

Since 2000
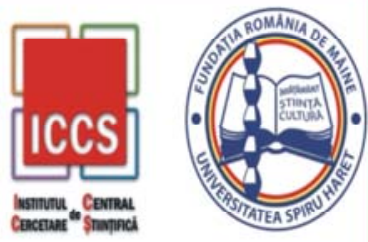

Issue 1/2019

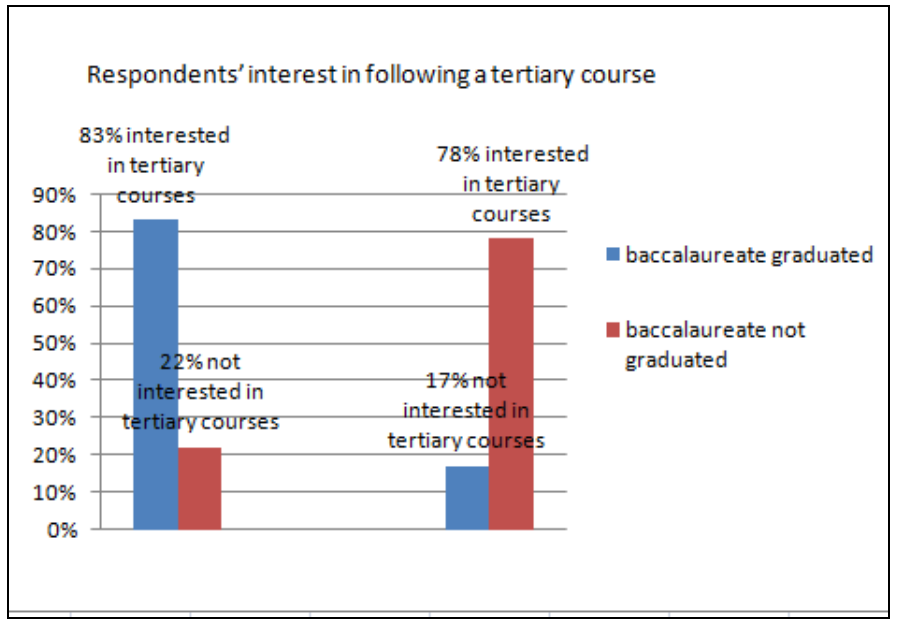

Fig. 1. Respondents' interest in following a tertiary course

The ninth question is: Do you consider that a tertiary course in the information technology specialisation, organized by Spiru Haret University, would be useful?; a great percentage of $98 \%$ answered affirmatively and only $2 \%$ answered negatively.

The last question: Would you recommend this course to your colleagues and acquaintances? also shows the opening for this type of course and for the actions and educational programmes offered by Spiru Haret University: 95\% answered yes and only $5 \%$ no.

In their turns, teachers recognize almost in $100 \%$ of the cases that they are not well informed about this type of education; that they did not promote this type of education to their pupils, as a consequence; that they are interested to find out more information about this type of educational route and that they would promote the course the Spiru Haret University would organize.

\section{Conclusions}

The sustainable future begins today with the most efficient long-term investment, which is the investment in education, in human resource. People have 28 


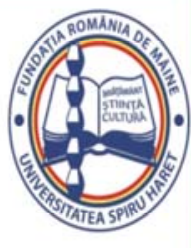

Issue 1/2019

to be prepared to build and sustain their future by themselves. The keys for the economic development are: knowledge, abilities and skills.

The natural and human capital are to be put together to lead to efficiency. We also note the lack of accurate information for young people, their vulnerability and their involvement; under these conditions, they are not able to make the best choice for their future profession.

In order to stimulate as well as possible the potential of the young baccalaureate graduated pupils, it is necessary that, at the level of the educational policies, the creativity of the educators and specialists be stimulated, so as the most required specialties on the labour market to be delivered.

\section{References}

[1] Amorati, Riccardo (2018). "Making Languages Marketable: An Analysis of a Promotional Brochure for Prospective Students in an Australian Tertiary Institution." Language Learning in Higher Education, vol. 8, issue 2, pp. 313-331, doi: 10.1515/cercles-2018-0018, https://eric.ed.gov/?id=EJ1193026

[2] Devis-Devis, Jose, Pereira-Garcia, Sofia, Fuentes-Miguel, Jorge, Lopez-Canada, Elena, \& Perez-Samaniego, Victor (2018). „Opening Up to Trans Persons in Physical EducationSport Tertiary Education: Two Case Studies of Recognition in Queer Pedagogy." Physical Education and Sport Pedagogy, Vol. 23, Issue 6, pp. 623-635, https://www.tandfonline.com/doi/abs/10.1080/17408989.2018.1485142

[3] Gair, Susan, \& Baglow, Len (2018). "Social Justice in a Tertiary Education Context: Do We Practice What We Preach?" Education Citizenship and Social Justice, Vol. 13, Issue 3, pp. 207-216, https://journals.sagepub.com/doi/abs/10.1177/1746197918793059

[4] Ghiorghiţă, Eugen (2015). "The influence of education and training on productive skills, nature of work and gender inequality," Annals of Spiru Haret University, vol. 15, nr. 2, p. 2, http://anale.spiruharet.ro/index.php/economics/article/view/1526/pdf

[5] Harvey, Hannah, \& Walsh, Sandra (2018). "Challenges and Opportunities in the Introduction of a Tertiary Education Program in Regional South Australia: A Case Study." Australian Journal of Teacher Education, Vol. 43, Issue 12, pp. 1-11, https://ro.ecu.edu.au/ cgi/viewcontent.cgi?article $=3883 \&$ context $=$ ajte

[6] https://www.edu.ro/sites/default/files/fisiere\%20articole/Strategie_inv_tertiar_2015_ 2020.pdf

[7] Ilić, Dragan, Milosavljević, Marko, \& Drain, Brain (2017). "Propulsive factors and consequences" Journal of Economic Development, Environment and People, volume 6, issue 4, pp. 29-30, http://ojs.spiruharet.ro/index.php/jedep/article/view/17644/pdf 
Annals of Spiru Haret University.

Economic Series

Since 2000

\section{Issue 1/2019}

[8] Isiyaku, Dauda Dansarki, Ayub, Mohd Ahmad Fauzi, \& AbdulKadir, Suhaida (2018). "Antecedents to Teachers' Perceptions of the Usefulness of ICTs for Business Education Classroom Instructions in Nigerian Tertiary Institutions." Asia Pacific Education Review, Vol. 19, Issue 3, pp. 337-352, DOI: 10.1007/s12564-018-9525-x, https://link.springer.com/article/10.1007/s12564-018-9525-x

[9] Naris, Sylvia N., \& Ukpere, Wilfred I. (2012). "The current state of staff development and training at a higher educational institution in Namibia," Annals of Spiru Haret University, vol. 12, nr. 1, p. 100, http://anale.spiruharet.ro/index.php/economics/article/view/1218/pdf

[10] Reyna, Jorge, \& Meier, Peter (2018). „Using the Learner-Generated Digital Media (LGDM) Framework in Tertiary Science Education: A Pilot Study." Education Sciences, vol. 8, issue 3, Doi: 10.3390/Educsci8030106, https://www.mdpi.com/2227-7102/8/3/106

[11] Terziev, Venelin, \& Arabska, Ekaterina (2015). “Application of New Instruments to Increase Effectiveness of Implementation of Social Policies on Labour Market in Bulgaria," Journal of Economic Development, Environment and People, volume 4, Issue 3, http://ojs.spiruharet.ro/index.php/jedep/article/view/116/pdf_103 